\title{
IDENTIFIKASI ARCA TOKOH BERKEPALA SINGA DI MUSEUM PENATARAN
}

\section{IDENTIFICATION OF A LION-HEADED FIGURE IN MUSEUM PENATARAN}

\author{
Ashar Murdihastomo \\ Pusat Penelitian Arkeologi Nasional \\ ashar.murdihastomo@kemdikbud.go.id
}

\begin{abstract}
The field study that was organized by the committee of Premodern Java Summer Programme in 2016 targeted several museums in East Java, especially in MojokertoPenataran area. That field study was intended to provide an understanding about the development of cultural arts during the end of Hindu-Buddhist period of Majapahit Kingdom. This paper is discussing about one of the objects that was being observed during that Summer Programme. The object of discussion is the lion-headed figure, stored in Museum Penataran. During the Summer Programme, some participants have predicted that the statue is Lord Vishnu in his Narasimha form. That prediction was mainly based on the statue's head which resemble a lion's head. Through several studies, such as the description of the statue, the literature study of iconography, and analysis about the special iconographic character, this paper concluded that this figure is a manifestation of Ganesha, named Simha-Ganapati. The worship of Simha-Ganapati has a purpose not only to bring strength and courage, but also to provide confidence in facing problems by destroying all forms of negative thoughts.
\end{abstract}

Keywords: Ganesha; Simha-Ganapati; Iconography; Archaeology

\begin{abstract}
ABSTRAK
Kunjungan lapangan yang diselenggarakan oleh panitia kegiatan Premodern Java Summer Programme tahun 2016 menargetkan beberapa museum di daerah Jawa Timur, khususnya di Mojokerto-Penataran. Kunjungan tersebut dimaksudkan untuk memberikan pemahaman mengenai perkembangan seni budaya masa akhir Hindu-Buddha di Kerajaan Majapahit. Artikel ini mengangkat salah satu objek yang menjadi bahan pengamatan pada kegiatan tersebut. Salah satu objek diskusi adalah arca berkepala singa di Museum Penataran. Beberapa peserta menduga arca tersebut adalah perwujudan dari Dewa Wisnu dalam bentuk Narasimha karena wajah arca yang berupa kepala singa. Melalui beberapa kajian, seperti deskripsi arca, kajian pustaka ikonografi, dan analisis ikonografis khusus, diperoleh hasil bahwa tokoh berkepala singa tersebut merupakan perwujudan dari Dewa Ganesha yang bernama Simha-Ganapati. Pemujaan terhadapnya bertujuan untuk menghadirkan kekuatan dan keberanian serta memberikan kepercayaan diri dalam menghadapi permasalahan dengan cara menghancurkan semua bentuk pikiran negatif.
\end{abstract}

Kata Kunci: Ganesha; Simha-Ganapati; Ikonografi; Arkeologi

Artikel Masuk $\quad$ : 25-03-2019

Artikel Diterima : :05-05-2019 


\section{PENDAHULUAN}

Pada tanggal 23 Juli hingga 2 Agustus 2016, diselenggarakan kegiatan Summer Programme in Southeast Asian Art History and Conservation oleh Nalanda University bekerjasama dengan ISEAS Yusof Ishak Institute, SOAS University of London dan UBAYA (Universitas Surabaya). Kegiatan tersebut mengambil tema Premodern Java yang berfokus pada perkembangan seni masa Hindu-Buddha akhir, tepatnya seni Kerajaan Majapahit, serta menggabungkan kegiatan kuliah dalam ruangan dengan kunjungan beberapa situs peninggalan Kerajaan Majapahit dan beberapa museum.

Salah satu museum yang dikunjungi dalam kegiatan tersebut adalah Museum Penataran yang berlokasi di Desa Penataran, Kecamatan Nglegok, Kabupaten Blitar. Museum ini merupakan pengembangan dari Museum Blitar, yang sebelumnya menempati area kompleks Pendopo Kabupaten Blitar, dalam rangka memaksimalkan fungsinya sebagai pusat pendidikan dan wisata. Pemerintah Kabupaten Blitar bekerja sama dengan Suaka Peninggalan Sejarah dan Purbakala Jawa Timur (sekarang Balai Pelestarian Cagar Budaya Jawa Timur) memindahkan seluruh koleksi Museum Blitar ke tempat baru di Museum Penataran. Letak Museum Penataran ini berjarak kurang lebih 500 meter di sebelah utara Kompleks Candi Penataran.

Museum Penataran ini memiliki tiga jenis koleksi, yakni arkeologi, etnografi, dan numismatik. Koleksi arkeologi dapat dilihat dari keberadaan arca, prasasti, relief, serta temuan lepas yang diindikasikan sebagai bagian struktur bangunan candi. Keberadaan koleksi etnografi dapat diketahui dari adanya benda-benda yang mengisyaratkan kehidupan masyarakat tradisional, seperti peralatan rumah tangga dan peralatan yang digunakan untuk bekerja. Sementara itu, koleksi numismatik yang ada di museum tersebut antara lain adalah uang logam berhuruf Cina dan uang kertas.

Ketika rombongan peserta Summer Programme berkunjung ke museum Penataran, pengelola museum mengajak para peserta mengunjungi salah satu tempat penyimpanan koleksi arca yang belum dipajang (semacam gudang). Tempat tersebut memiliki cukup banyak koleksi yang cukup menarik. Rata-rata koleksi tersebut adalah arca dewa-dewi agama Hindu. Beberapa koleksi yang ada di tempat tersebut menarik perhatian para peserta. Terdapat satu arca batu yang menjadi "primadona" para peserta karena memiliki bentuk yang sangat jarang dijumpai. Arca tersebut memiliki kepala dengan wajah berbentuk singa dan digambarkan dengan perut buncit (tundila) serta posisi duduk bersila dengan kedua telapak kaki saling bersentuhan sama lain (utkutikasana). Banyak peserta yang kemudian berdiskusi terkait dengan arca tersebut. Hasil diskusi tersebut kemudian menginterpretasikan arca tersebut sebagai Narasimha, yaitu salah satu perwujudan Wisnu yang turun ke dunia dalam wujud manusia berkepala singa.

Pendapat tentang nama tokoh arca tersebut sebagai Narasimha dirasa kurang tepat. Hal ini dikarenakan adanya perbedaan ciri-ciri yang terdapat pada arca dengan gambaran tokoh Narasimha. Oleh karena itu, pada kesempatan ini penulis mencoba membahas tokoh arca tersebut dengan fokus pada pertanyaan "Siapakah tokoh yang diarcakan dengan kepala singa tersebut?". Tujuan yang ingin dicapai adalah menentukan nama tokoh arca berdasarkan pada ciri-ciri ikonografis khusus yang melekat padanya. Manfaat yang diperoleh dari hal 
tersebut adalah memberikan informasi, baik kepada Pengelola Museum Penataran maupun pengunjung tentang nama tokoh yang diarcakan. Selain itu, informasi tersebut juga dapat bermanfaat bagi perkembangan ilmu arkeologi, terutama pada kajian ikonografi karena identifikasi tokoh arca baru dapat menambah daftar tokoh dewa-dewi yang dipuja oleh masyarakat pada masa lalu, khususnya pada masa pengaruh Hindu-Buddha di Jawa Timur.

Keberadaan singa dalam budaya Hindu-Buddha, baik di India maupun Nusantara, bukanlah hal yang mengherankan. Singa merupakan salah satu binatang yang populer. Kepopuleran ini disebabkan oleh adanya anggapan binatang singa sebagai penguasa hutan (Ray, 1977, hlm. 8). Asumsi sebagai penguasa rimba ini muncul, kemungkinan, karena singa merupakan hewan predator tertinggi yang tidak memiliki musuh alami. Selain itu, melalui hasil studi terkait perilaku terhadap singa diperoleh informasi bahwa sistem sosial pada kelompok singa menempatkan aktivitas berburu didominasi oleh betina, sedangkan jantan sebagai pelindung kelompok. Hal inilah yang menjadikan singa dianggap sebagai simbol suatu pelindung (Restiyadi, 2012, hlm. 5).

Selain sebagai pelindung, singa juga sering direpresentasikan dengan aspek lain. Binatang ini juga sering disandingkan dengan matahari karena memiliki warna kuning tua dan memiliki bulu tengkuk lebat berwarna emas yang berkilau (Nozedar, 2008). Warna emasnya tersebut juga dianggap sebagai gambaran dari sifat kebangsawanan dan perlindungan (Choskyi, 1988). Oleh karena itu, tidak mengherankan apabila singa sering digunakan sebagai simbol suatu kerajaan yang menggambarkan kemuliaan, keagungan, dan kebanggaan (Khosravifard dan Niamir, 2016, hlm. 1).

Dalam agama Hindu, singa dipahatkan menghiasi kuil-kuil pemujaan. Binatang tersebut sering digambarkan bersama dengan kuda, gajah, angsa, dan lembu (Geer, 2008, hlm. 334 dan Restiyadi, 2012, hlm. 6). Penggambaran binatang tersebut di sebuah kuil menunjukkan bahwa posisi mereka dianggap penting. Anggapan ini sejalan dengan konsepsi dalam agama Hindu bahwa seluruh bentuk kehidupan, mulai dari yang kecil hingga yang besar, dianggap sakral. Dalam teks keagamaan kuno disebutkan daftar hewan yang dianggap suci, antara lain invertebrata (lebah, kupu-kupu, moluska, laba-laba), ikan, reptil (buaya, kadal, ular, tupai, kura-kura), burung (elang, elang, gagak, derek, angsa, elang, burung hantu, burung merak, angsa, merpati), dan mamalia (kelelawar, beruang, babi hutan, kerbau, banteng, kucing, sapi, anjing, rusa, gajah, rubah, kambing, kuda, macan tutul, singa, monyet, tikus, harimau, kelinci). Hanya perlu ditekankan bahwa dari sekian banyak hewan tersebut ada beberapa hewan yang dianggap lebih tinggi derajatnya yang salah satunya adalah singa (Agoramoorthy dan Hsu, 2012, hlm. 6).

Posisi penting singa dalam agama Hindu ini terlihat dari keberadaannya yang cukup sering muncul dalam kitab Veda. Kemunculan tersebut dapat diwujudkan dalam bentuk tokoh dewa ataupun wahana (kendaraan) dewa. Dalam bentuk tokoh dewa, singa muncul sebagai perwujudan Wisnu yang bernama Narasimha, yaitu manusia berkepala singa. Singa sebagai wahana atau kendaraan bagi dewa ataupun dewi dapat dicontohkan berupa kendaraan dari Dewi Durga. Selain itu, singa juga sering diwujudkan dalam arca tersendiri sebagai penjaga pintu masuk bangunan suci serta menjadi landasan tahta bagi 
Dewa atau Raja (Geer, 2008, hlm. 334). Keberadaan simbol singa di depan bangunan suci dan tahta tersebut merupakan salah satu aspek yang dapat menunjukkan sifat keagungan (Haryono, 1980, hlm. 46-49 dan Nilotama, 2009, hlm. 54-55).

Sementara itu, sejarah penggunaan simbol singa dalam agama Buddha ditemukan pada masa Raja Ashoka (273 SM-232 SM) yang membangun beberapa pilar yang di dalamnya mengandung unsur singa. Simbol singa dalam agama Buddha ini merupakan simbol dari Buddha itu sendiri. Buddha (Siddharta Gautama) dianggap sebagai manusia yang mulia, Great Man. Selain itu, sang Buddha juga dianggap sebagai gambaran dari hewan-hewan terkuat, seperti Singa (Mahāsimha), Gajah (Mahānāga), dan banteng (Narārsabha) (Ohnuma, 2016, hlm. 21). Simbol singa juga merujuk pada asal dari keluarganya, Sakya, yang menganggap Siddharta sebagai singa dari keluarga Sakya (Säkya-sinha) yang keseluruhan representasinya merujuk pada tubuh singa, yaitu bahu yang lebar dan kuat serta kelenturan tubuhnya yang menunjukkan kekuatan spiritual, sebuah kualitas yang berasal dari inkarnasi dari sepuluh raja binatang (singa), sikapnya menunjukkan doktrin yang diajarkannya disebut sebagai hukum singa, perkataannya seperti auman singa, dan juga singa menjadi penopang padmāsananya (Ball, 2004, hlm. 53 dan Restiyadi, 2012, hlm. 9).

Simbol singa juga sering digunakan sebagai penanda dari Bodhisattwa yang sering disebut sebagai anak-anak Buddha (juga sering disebut sebagai singasinga Buddha). Bodhisattwa merupakan makhluk yang telah mencapai tingkatan spiritual yang tinggi. Dalam posisi tersebut, Bodhisattwa menunda untuk masuk nirwana karena masih berusaha untuk tetap berada di dunia untuk membantu makhluk hidup bebas dari penderitaan. Selain itu, dalam aspek ikonografi, singa memiliki peran sebagai penjaga dharma serta mendukung tahta Buddha dan Bodhisattwa. Sifat ini dapat dilihat pada penggambaran sebagai hewan penjaga pintu masuk bangunan suci maupun penjaga singgasana Buddha dan Bodhisattwa (Choskyi, 1988). Beberapa contoh simbolisasi ini adalah Simhanada (auman singa) yang merupakan salah satu perwujudan dari Bodhisattwa Avalokiteşvara. Singa juga menjadi wahana atau kendaraan dari para Boddhisattwa seperti Vaishravana, Manjushri, Ratnasambhwa dan Vairocana. Singa juga memiliki peran sebagai pelindung dharma yang digambarkan menjadi landasan dari arca Buddha atau Bodhisattwa. Selain itu arca-arca singa juga ditemukan pada pintu masuk kuil-kuil Buddha (Restiyadi, 2012, hlm. 7).

Keterangan menyebutkan bahwa simbol singa dalam agama Hindu dan Buddha menduduki peran penting. Pertama, singa merupakan wujud dari tokoh suci. Kedua, singa merupakan kendaraan bagi para dewa. Terakhir, penggambaran binatang singa di depan bangunan suci digunakan sebagai penolak aura jahat yang akan masuk.

\section{METODE}

Upaya identifikasi tokoh arca dilakukan melalui beberapa langkah. Pertama, melakukan pengamatan langsung dan pendokumentasian. Pengamatan langsung dilakukan untuk mendapatkan informasi detail terkait arca tersebut. Hasil pengamatan kemudian ditulis dalam bentuk deskripsi arca. Penulisan data 
deskripsi arca ini dibantu dengan dokumentasi foto untuk mengecek apabila ada pengamatan yang terlewat. Dokumentasi dilakukan dalam dua bentuk yaitu keseluruhan dan detail. Kedua, melakukan kajian pustaka melalui buku, artikel ilmiah, dan informasi tertulis yang diperoleh di internet. Informasi yang coba diperoleh dari kajian pustaka adalah terkait dengan ikonografi dan ikonologi dewa-dewi Hindu, dengan harapan dapat mengetahui nama dari tokoh yang diarcakan. Tahap kajian pustaka berikutnya adalah memperdalam mitologi tokoh tersebut untuk mengetahui perannya dalam lingkungan masyarakat. Hasil akhir dari deskripsi dan kajian pustaka tersebut kemudian saling dikaitkan satu sama lain untuk kemudian dapat digunakan untuk menjawab pertanyaan yang diajukan.

\section{HASIL PENELITIAN}

\section{Deskripsi Arca}

Arca tokoh berkepala singa di Museum Penataran ini ditempatkan pada ruang penyimpanan bersama dengan beberapa koleksi arca lainnya. Pada arca ini ditempel kertas dengan tulisan angka 121 yang merupakan nomor urut koleksi di ruangan tersebut. Secara ukuran, arca ini memiliki tinggi sekitar $81 \mathrm{~cm}$, lebar sekitar $34 \mathrm{~cm}$, dan tebal sekitar $36 \mathrm{~cm}$. Arca dibuat dengan teknik pahat pada sebuah batu monolit yang berjenis batu andesit.

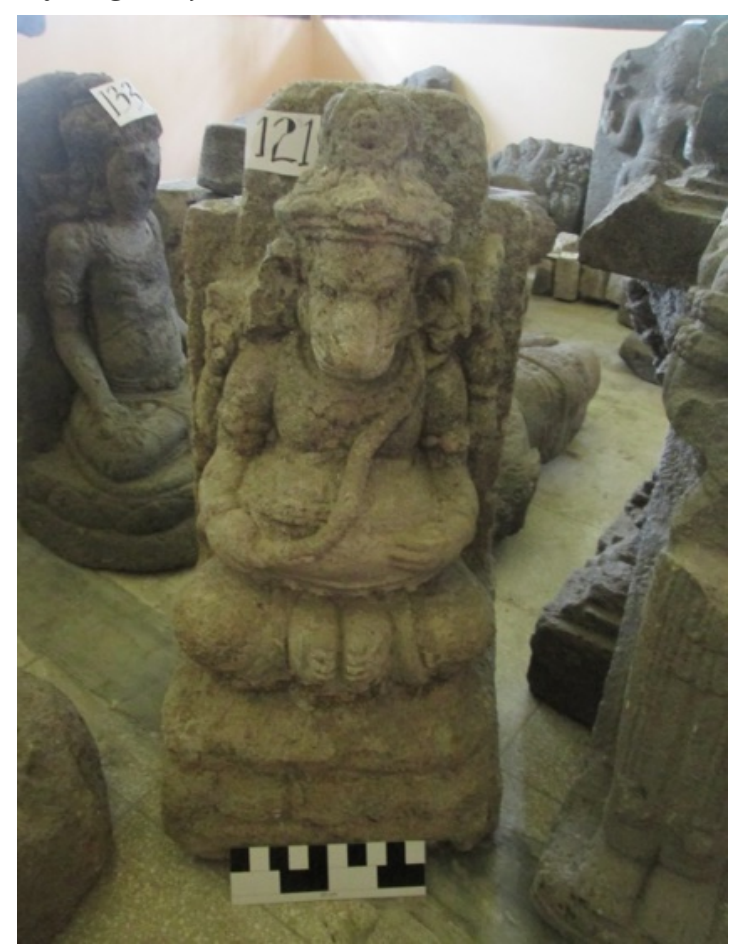

Gambar 1. Arca Berkepala Singa Tampak Depan (Sumber: Murdihastomo, 2016)

Secara umum, arca ini digambarkan duduk di atas landasan (asana) yang berbentuk padma, disebut dengan padmāsana. Arca juga digambarkan memiliki 
sandaran duduk (stela), serta memiliki lingkaran kedewataan (sirascakra) di belakang kepala. Tokoh ini digambarkan memiliki wajah singa, pada dahi terdapat goresan yang diperkirakan adalah trinetra, duduk dalam posisi telapak kaki saling bersentuhan (utkutikasana), memiliki perut buncit (tundila) dan memiliki empat tangan, dua tangan di depan memegang perut, sedangkan kedua tangan di belakang memegang benda, tangan kanan memegang untaian mutiara atau tasbih atau aksamala sedangkan tangan kiri memegang kapak atau parasu.

Secara ikonografis, tokoh ini digambarkan menggenakan pakaian yang cukup raya. Beberapa ciri pakaian (abharana) yang dikenakan tokoh ini antara lain, memiliki mahkota dengan jenis jatamakuta. Mahkota dihiasi ornamen tengkorak dan bulan sabit (ardhacandrakapala) dibagian depan. Tokoh ini juga memakai hiasan kepala berupa jamang. Hiasan lain yang dikenakan antara lain adalah kalung (hara), hiasan menyamping badan (upavita) berwujud ular, hiasan melintang perut (udarabandha), hiasan lengan (keyura), gelang (kankana), mengenakan pakaian bawah hingga mata kaki (antarvasaka), dan gelang kaki (padasaras).

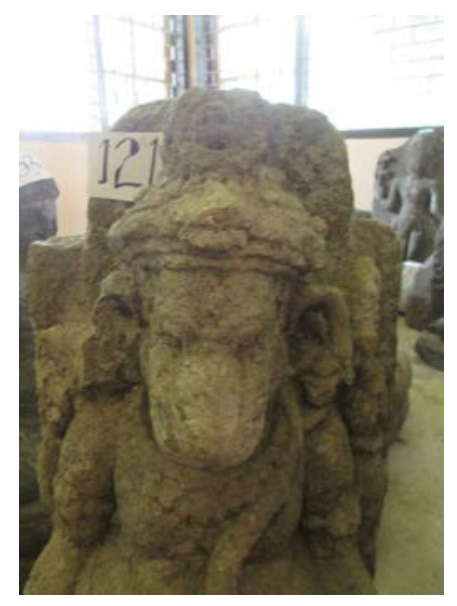

Gambar 2. Detail Kepala Arca (Sumber: Murdihastomo, 2016)

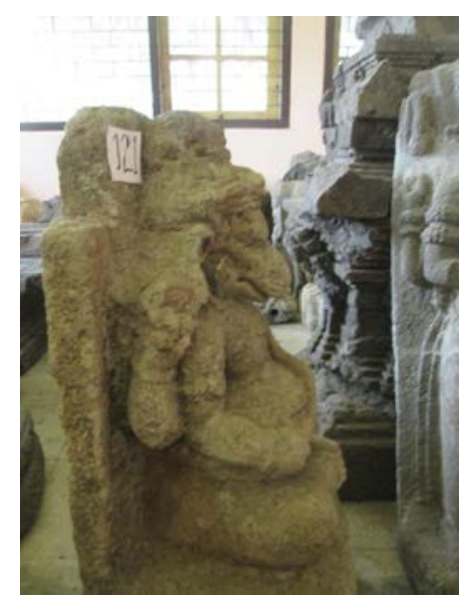

Gambar 3. Arca Tampak Samping Kanan (Sumber: Murdihastomo 2016)

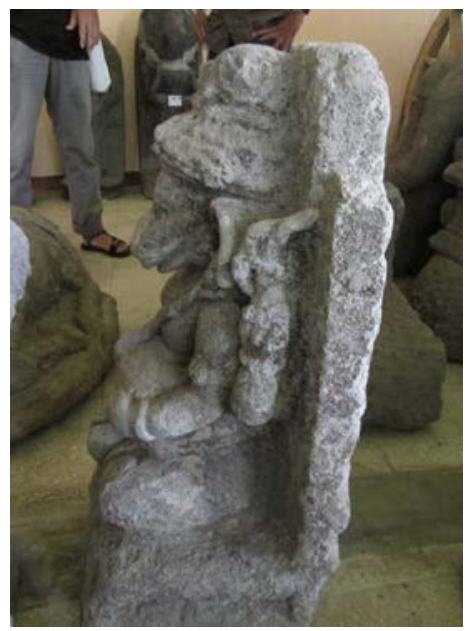

Gambar 4. Arca Tampak Samping Kiri (Sumber: Murdihastomo, 2016) 


\section{DISKUSI DAN PEMBAHASAN}

\section{Identifikasi Tokoh Arca Museum Penataran}

Telah disebutkan pada bagian permulaan bahwa beberapa peserta Summer Programme 2016 yang mengikuti kunjungan ke Museum Penataran memiliki keyakinan bahwa arca tokoh berkepala singa tersebut merupakan perwujudan dari Narasimha, yaitu salah satu dari awatara Dewa Wisnu. Asumsi ini didasarkan pada wujud kepala yang berupa kepala singa, tanpa melihat atribut atau ciri lainnya. Hal ini tentu tidak memiliki kekuatan yang cukup karena hanya berdasarkan pada satu atribut saja. Oleh karena itu, pada kesempatan ini penulis berusaha menjabarkan ciri-ciri tokoh Narasimha terlebih dahulu.

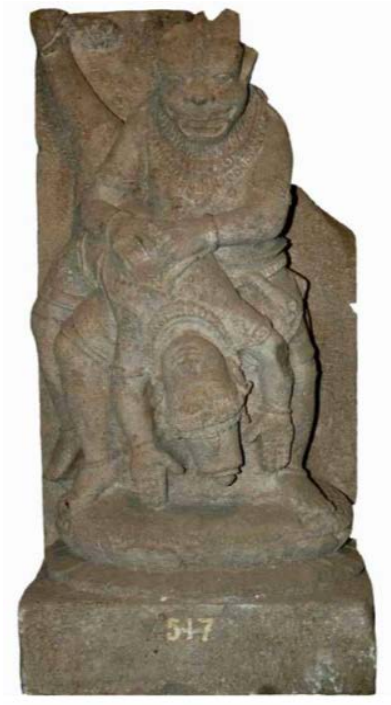

Gambar 5. Arca Narasimha Koleksi BPCB D.I. Yogyakarta

(Sumber: BPCB D.I. Yogyakarta, 2014)

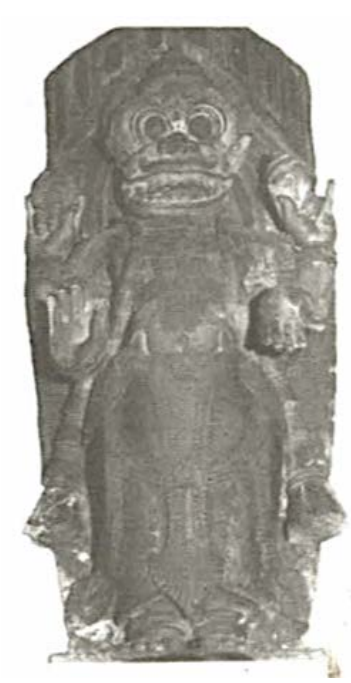

Gambar 6. Arca Kevala Narasimha (Sumber: Nayar, 2016)

Pencarian informasi mengenai ciri-ciri tokoh Narsimha dapat dilihat dari temuan arca yang kini disimpan di kantor Balai Pelestarian Cagar Budaya (BPCB) D.I. Yogyakarta. Arca Narasimha koleksi BPCB Yogyakarta tersebut ditemukan di dekat Candi Ijo yang dipahatkan pada satu batuan monolit. Arca tersebut terdiri atas dua tokoh, tokoh utama (Narasimha) dan tokoh penyerta (Hiranyakasipu). Tokoh utama digambarkan berdiri di atas padmāsana sementara tokoh penyerta digambarkan pada posisi terbalik yang bertumpu pada paha tokoh utama. Narasimha diwujudkan dalam bentuk antropomorfik (tubuh manusia berkepala singa) yang digambarkan memiliki dua buah tangan yang sedang membelah dada Hiranyakasipu (Hadiyanta, Romawati, dan Tanzaq, 2014, hlm. 30-31).

Gambaran lain dapat diperoleh dari artikel yang ditulis oleh Preeta Nayar. Dalam artikelnya dicantumkan beberapa foto tentang berbagai wujud Narasimha, yaitu Kevala-Narasimha, Yoga-Narasimha, dan Sthauna-Narasimha (Nayar, 2016, hlm. 175-178). Ketiga arca tersebut digambarkan dalam posisi yang berbeda-beda. Arca Kevala-Narasimha digambarkan dalam posisi berdiri lurus (samabhanga). Arca 
ini memiliki empat buah tangan dengan tangan kanan depan bersikap abhaya mudra sedangkan tangan kiri depan bersikap varada mudra, sementara tangan kanan belakang memegang chakra dan tangan kiri belakang memegang sankha. Arca Yoga-Narasimha digambarkan dalam posisi duduk. Posisi duduk ini dikatakan sebagai utkutikasana dengan atribut yogapata untuk menyangga kakinya. Arca digambarkan bertangan empat, dua tangan bagian depan diletakkan di atas kaki sementara dua tangan di belakang memegang chakra di kanan dan sankha di kiri. Sthauna-Narasimha merupakan arca yang digambarkan dalam satu kesatuan dengan tokoh Hiranyakasipu. Arca ini digambarkan duduk dalam posisi ardhaparyanka dengan kaki kiri ditekuk sementara kaki kanan menjuntai ke bawah. Tokoh Narasimha digambarkan memiliki empat pasang tangan, sepasang tangan merobek dada Hiranyakasipu, sepasang tangan menahan badan Hiranyakasipu, sepasang tangan menarik isi dada, dan sepasang tangan di belakang memegang chakra di sisi kanan dan sankha di sisi kiri. Sementara itu, tokoh Hiranyakasipu terlihat membawa pedang (khadga) di tangan kanan dan perisai (khetaka) di tangan kiri

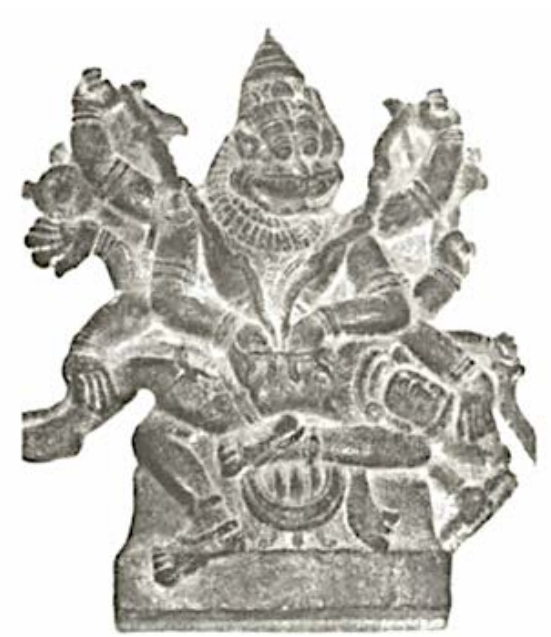

Gambar 7. Arca Sthauna-Narasimha (Sumber: Nayar, 2016)

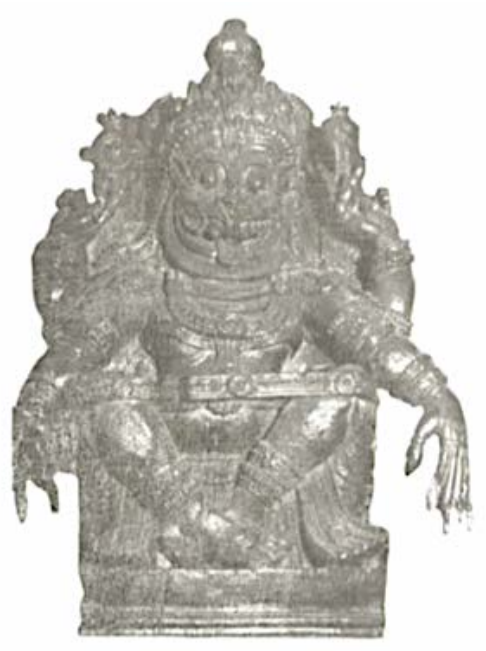

Gambar 8. Arca Yoga-Narasimha (Sumber: Nayar, 2016)

Dari keterangan tentang Narasimha di atas diketahui bahwa tokoh Narasimha digambarkan memiliki atribut tertentu, yaitu kepala singa, keberadaan chakra dan sankha, serta tokoh penyerta berupa Hiranyakasipu. Keberadaan atribut tersebut tidak dijumpai pada tokoh arca kepala singa Museum Penataran. Tokoh di Museum Penataran tersebut memiliki beberapa atribut khusus berupa hiasan tengkorak dan bulan sabit (ardhacandrakapala), mata ketiga (trinetra), upavita ular, tasbih (aksamala), kapak (parasu), dan perut buncit (tundila). Berdasarkan pada penelitian yang dilakukan oleh (Sedyawati, 1994, hlm. 65) diketahui bahwa mata ketiga, perut buncit, upawita ular, tengkorak dan bulan sabit sebagai hiasan mahkota merupakan salah satu ciri ikonografik ke-Siwa-an. Salah satu tokoh yang memiliki ciri tersebut adalah Ganesha. Dewa Ganesha ini juga memiliki ciri ikonografis khusus lainnya terkait dengan tanda yang ada di tangannya. Tokoh ini digambarkan memiliki empat tangan, dua tangan di belakang didominasi 
tangan yang memegang tasbih dan kapak (Sedyawati, 1994, hlm. 76). Untuk memperjelas gambaran tersebut, maka berikut ini akan ditampilkan empat foto arca Ganesha dari beberapa lokasi sebagai perbandingan.

Arca Ganesha yang digunakan perbandingan terdiri atas arca yang berada di Kantor BPCB Jawa Tengah, Koleksi Museum Nasional, Candi Prambanan, dan Arca Koleksi Museum Penataran. Secara umum, keempat arca tersebut digambarkan mengenakan pakaian bangsawan, berkepala gajah dengan belalai mengarah ke arah kiri, duduk dengan sikap utkutikasana, berperut buncit, dan bertangan empat.

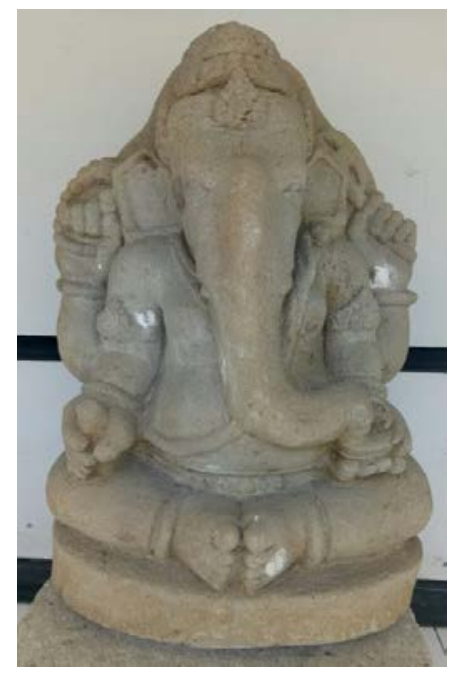

Gambar 9. Arca Ganesha Koleksi BPCB Jawa Tengah (Sumber: BPCB Jawa Tengah)

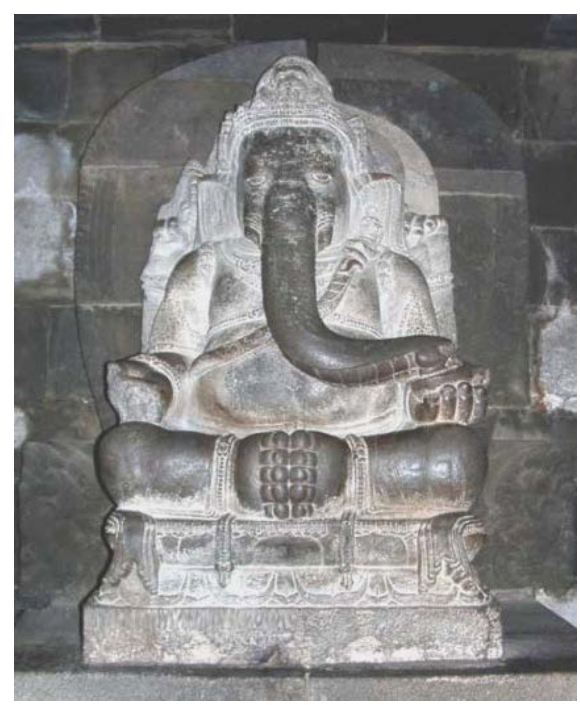

Gambar 11. Arca Ganesha Candi Prambanan (Sumber: Perpustakaan Nasional)

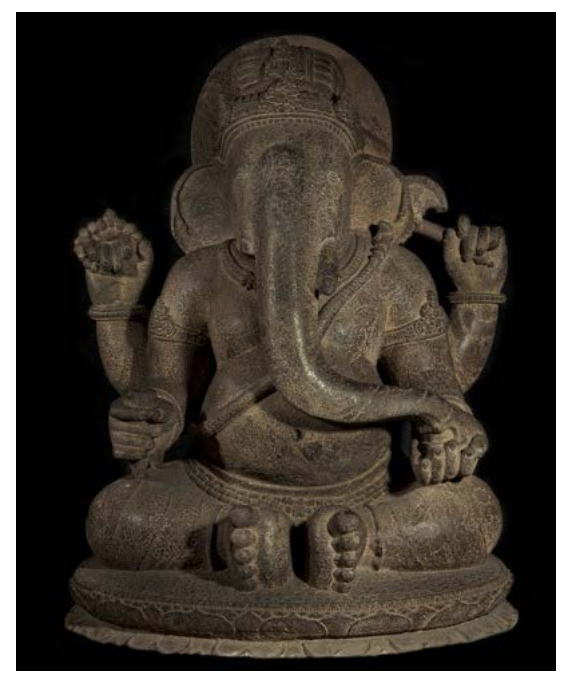

Gambar 10. Arca Ganesha Koleksi Museum Nasional (Sumber: Museum Nasional)

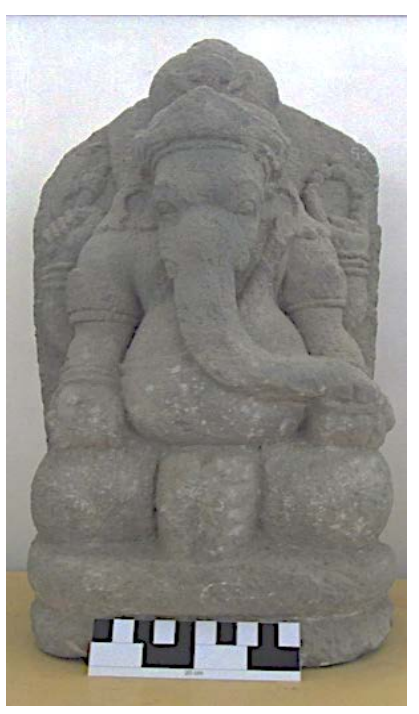

Gambar 12. Arca Ganesha Museum Penataran (Sumber: Murdihastomo, 2016) 
Arca Ganesha yang berada di kantor BPCB Jawa Tengah memiliki ciri ikonografik khusus antara lain, trinetra, aksamala, parasu, upawita ular, dan perut buncit (tundila). Arca Ganesha yang berada di Museum Nasional memiliki ciri ikonografik khusus antara lain, aksamala, parasu, upawita ular, dan tundila. Arca Ganesha yang berada di Candi Prambanan memiliki ciri ikonografik khusus antara lain, archacandrakapala, trinetra, aksamala, parasu, upawita ular, dan tundila. Arca Ganesha koleksi Museum Penataran memiliki ciri ikonografik khusus antara lain, ardhacandrakapala, aksamala, parasu, upawita ular, tundila. Dari keterangan yang diperoleh dari Sedyawati serta adanya gambaran dari keempat foto di atas maka tidak dapat dipungkiri bahwa Ganesha memiliki tanda-tanda ke-Siwa-an. Tentunya hal tersebut tidak mengherankan karena Ganesha adalah putra dari Siwa.

Keberadaan atribut-atribut yang mencirikan ke-Siwa-an tersebut ternyata juga dimiliki oleh arca yang ada di Museum Penataran. Pada bagian sebelumnya, terutama pada deksripsi arca, telah disebutkan bahwa arca tokoh tersebut digambarkan memiliki trinetra, upavita ular, tundila, serta memegang aksamala di tangan kanan dan parasu di tangan kiri. Ciri-ciri yang dimiliki oleh arca di Museum Penataran tersebut cenderung lebih dekat dengan tokoh Ganesha daripada Narasimha. Sehingga, diperkirakan bahwa tokoh yang diarcakan tersebut adalah tokoh Ganesha dalam salah satu wujudnya.

\section{Perwujudan Ganesha}

Dewa-dewi dalam agama Hindu merupakan tokoh suci yang memiliki beragam sebutan nama. Nama-nama yang diberikan kepada dewa/dewi ini disesuaikan dengan mitologinya atau cerita mitos yang menyebabkan dewa/dewi ini dikenai dengan nama tersebut. Penyebutan nama ini dapat diindikasikan dari bentuk tubuh, menyebut salah satu bagian tubuh, lawan yang dihadapi, hingga cara untuk melawan raksasa jahat. Selain itu, keberadaan nama tersebut juga sering dikaitkan dengan kelahiran kembali atau sering disebut dengan inkarnasi atau awatara. Hal ini tidaklah mengherankan karena tugas dewa adalah sebagai penolong umat manusia.

Dalam agama Hindu, terdapat beberapa dewa yang memiliki beragam perwujudan. Beberapa dewa yang diketahui memiliki beberapa perwujudan itu adalah Dewa Siwa dan Wisnu. Dewa Siwa yang terkenal sebagai dewa penghancur memiliki beberapa perwujudan dalam aspek Mahesamurti dan Sadasiwamurti (Soedibyo, 1984, hlm. 14-16). Dewa Wisnu yang dikenal sebagai dewa penjaga dunia juga memiliki beberapa perwujudan. Perwujudan dewa Wisnu yang terkenal terdiri atas sepuluh awatara, yaitu, Matysa, Kurma, Varaha, Narasimha, Vamana, Parashurama, Rama, Khrisna, Buddha, dan Kalki (Rao, 1914: 120). Keseluruhan perwujudan baik dari Dewa Siwa maupun Wisnu memiliki tugas masing-masing yang disesuaikan dengan tujuan perwujudannya.

Ganesha, sebagai salah satu tokoh yang populer bagi umat Hindu, juga tidak terlepas dari keberadaannya dalam berbagai wujud. Berdasarkan pada mitologinya, (Jouveau-Dubreuil, 1937, hlm. 40) menyebutkan bahwa Ganesha dipuja sebagai dewa kebajikan yang memiliki kekuatan untuk menghilangkan segala kesulitan dan sering dipuja dengan nama Ganapati, Vighnesvara dan Vināyaka. Ganesha disebut dengan berbagai nama, Vakratunda, Ekadanta, Vināyaka, 
Ganapali, Heramba, Vighnesvara, Akhu-Ratha, Siddhidata, Dvi-Dehaka, Lambodara, Gajanana, dan Bala-ganapati (Suresh, 1991, hlm. 295). Selain itu (Suresh, 1991, hlm. 298) menyebutkan bahwa Ganesha dengan nama Ganapati merupakan dewa penting yang berkembang pada abad ke-10 masehi ketika sekte Ganapatya membentuk pemujaan Sakti-Ganapati antara lain Ucchist-Ganapati, Maha-Ganapati, Urdhva-ganapati, Pingala-Ganapati, dan Lakshmi-Ganapati. Dalam suatu kisah disebutkan bahwa nama Ganesha yang beragam ini diberikan oleh Dewa Wisnu setelah dia berhasil mendapatkan kepala untuk anak dari Dewi Parvati. Dewa Wisnu kemudian memberikan delapan nama yaitu Vighnesvara, Ganesha, Heramba, Gajanana, Lambodara, Ekadanta, Soorpakarna, dan Vināyaka (Deka, 2010: 19). Mitologi lainnya menyebutkan bahwa perwujudan Ganesha dapat dibedakan kedalam empat masa Yuga, yaitu Mahotkaca (Mahotkata) yang muncul pada masa Krita Yuga, Shri Mayureshvar yang muncul pada masa Treta Yuga, Shri Gajanana yang muncul pada masa Dwapara Yuga, dan Dhumraketu yang merupakan perwujudan Ganesha yang akan muncul di masa depan pada masa Kaliyuga (Chinmayananda, 1986, hlm. 41).

Hampir sama dengan catatan di atas, Rao juga menyebutkan bahwa Ganesha memiliki beragam bentuk dan pahatan yang dapat dijumpai pada hasil budaya agama Hindu di India. Beberapa wujud yang dapat dijumpai antara lain adalah Bala-Ganapati, Taruna Ganapati, Vira Ganesha, Bhakti Vighnesvara, Sakti Ganesha, Lakshmi Ganesha, Heramba Ganesha, Prasanna Ganesha, Unmatta Ganesha, Gajanana, Vighnaraja, Bhuva Ganesha, Nrittya Ganesha, Ekadanta Ganesha (Rao, 1914, hlm. 52-60). Pada proses pemberian persembahan, Ganesha disebut dengan 21 nama, antara lain Vighnaraja, Gajañana, Lambodara, Shivatmaja, Vakratunda, Supakarna, Ganeshvara, Vighnanashin, Vikata, Vamana, Sarvadeva, Sarvadukhavinaŝshi, Vighnarhartr, Dhuîraja, Sarvadevaidhideva, Ekadanta, Krishnapingala, Bhalachandra, Gananatha, Shankarasunav, dan Anangapujita (Kumaran, tanpa tahun: tanpa halaman)

Keberadaan perwujudan Ganesha juga tercantum dalam beberapa teks kuno. Dalam Taittiriya Aranyaka dan Narayana Upanishad, Ganesha sering disebut sebagai Vakratunda dan Danti (Dantin) (Gupte, 1972, hlm. 47 dan Reddy, 1995, hlm. 36). Dalam Atharva Shirsha, dia disebut sebagai Ekadanta, Vakratunda, dan Danti. Dalam Boudhayana-Dharma-Sutra, Ganapati disebut dengan Vighna, Vināyaka, Sihula, Hastimukha, Vakratunda, Ekdanta, dan Lambodara (Gupte, 1972, hlm. 48). Selain itu Gupte juga menyebutkan dalam bukunya bahwa Ganesha memiliki 11 wujud, antara lain adalah Heramba, Prasanna-Ganapati, Dhvaja-Ganapati, UnmattaUchhhishta-Ganapati, Bhuvanesa-Ganapati, Nritta-Ganapati, Haridra-Ganapati/ RatriGanapati, Bala-Ganapati, Taruna-Ganapati, Bhakti-Vighnesvara, Vira-Vighnesa (Gupte, 1972, hlm. 80). Dalam Mudgala Purana dikenal delapan inkarnasi Ganesha, yaitu Vakratunda, Ekadanta, Mahodara, Gajanana, Lambodara, Vikata, dan Vighnaraja (Chinmayananda, 1986, hlm. 60). Dalam Ganesha Purana juga disebutkan 12 wujud utama dari dewa berkepala gajah (merujuk kepada Ganesha), yaitu Sumukha, Ekadanta, Kapila, Gajakarna, Lambodara, Vikata, Vighnanaŝaka, Ganaîhipa, Dhuînraketu, Ganadhyaksha, Bhalachandra, dan Gajanana (Kumaran, tanpa tahun: tanpa halaman). Brahmavaivarta Purana menyebutkan bahwa Ganesha adalah Krishna serta dalam Baudhayana-Dharma-Sutra Ganapati sering disebut sebagai 
Vighna, Vināyaka, Sthula, Hastimukha, Vakratunda, Ekadanta dan Lambodara (Kouli, 2012, hlm. 108).

Temuan nama Ganesha di teks lainnya juga dijabarkan oleh Redig, antara lain dalam Skanda Purana membagi dalam dua kelompok, yaitu kelompok enam dan kelompok delapan. Pada kelompok enam Ganesha disebut dengan Rddhida, Siddhida, Kamada, Vighnaha, Pramodi dan Caturhivratakapriya sedangkan pada kelompok delapan Ganesha disebut dengan Arka-Vināyaka, Durga-Vināyaka, Bhimacanda-Vināyaka, Dehali-Vināyaka, Uddanda-Vināyaka, Pasapani-Vināyaka, Kharva-Vianyaka, dan Siddhi-Vināyaka (Redig, 1992, hlm. 21). Selain itu, dalam Sankaradigvijaya Anandagiri Ganesha memiliki beberapa nama, yaitu Mahaganapati,

Haridraganapati, Ucchistaganapati, Navanitaganapati, Svarnaganapati, dan Samtanaganapati (Redig, 1992, hlm. 21). Brahmanda Purana menyebutkan nama lain Ganesha dengan Gajanana, Balacandra, Surpakarnaka, Vighnanasaka, Ekadanta, Vakratunda (Redig, 1992, hlm. 22). Brahmavaivarta Purana memuat nama Ganesha dengan sebutan Parabrahman, Ekadanta, Heramba, Lambodara, Gajanana, Guhagraja (Redig, 1992, hlm. 22-23). Matsya Purana menyebut Ganesha sebagai Gangeya dan dalam Skanda Purana disebut Landdukapriya (Redig, 1992, hlm. 23). Selain teks, nama Ganesha ditemukan disebutkan pada hymne yang ada di Rigveda, Aitareya dan Sankhayana Brahmana sebagai Brahmanaspati (Reddy, 1995, hlm. 36).

Perwujudan Ganesha yang cukup lengkap dapat dijumpai pada buku karangan (Bühnemann, 1955, hlm. 1). Informasi yang diperoleh dari buku tersebut menyatakan bahwa Ganapati merupakan salah satu dewa umum yang dijumpai di India dan begitu terkenal di India Selatan. Dewa ini memiliki banyak bentuk, dengan memiliki 2, 6, 8, 10, 12, 18 atau lebih tangan serta dengan 1, 2, 3, 4 atau 5 kepala. Bentuk-bentuk tersebut dapat digambarkan secara mandiri atau bersama dengan satu atau dua pendamping. Dari hasil kajiannya, terdapat beberapa kelompok nama Ganesha yang ditemukan dan dipuja. Terdapat empat kelompok yang disesuaikan dengan jumlah perwujudannya antara lain kelompok 16, kelompok 32, kelompok 51 dan kelompok 56 (lihat lampiran 1-4). Kelompok 16 merupakan perwujudan Ganesha yang sering dijumpai di India Selatan baik dalam teks maupun dipahatkan pada kuil. Kelompok 16 tersebut merupakan bagian dari kelompok 32 yang disebutkan dalam teks Sritattvanidhi. Kelompok 51 merupakan perwujudan Ganesha yang digambarkan bersama dengan pasangannya. Sedangkan kelompok 56 merupakan nama-nama Ganesha berada pada lingkaran Mandala Kasi yang bertujuan untuk melindungi suatu kota (Bühnemann, 1955, hlm. 2-15).

\section{Ganesha Berwajah Singa}

Berdasarkan pada keterangan terkait dengan perwujudan Dewa Ganesha, ditemukan beberapa perwujudan yang berasosiasi dengan binatang singa, yaitu Heramba, Mahotkata-Vināyaka, Vakratunda, Pancamukha-Ganapati, dan SimhaGanapati. Dari kelima wujud Ganesha tersebut hanya Simha-Ganapati yang dijelaskan sebagai Ganesha berwajah singa, sementara empat lainnya merupakan nama lain Ganesha yang mengendarai atau memiliki wahana berupa binatang singa (Bühnemann, 1955, hlm. 10).

Keberadaan wahana dalam seni kuno Hindu sering digambarkan dalam bentuk zoomorfik maupun antropomorfik. Dalam bentuk zoomorfik berarti 
wahana tersebut digambarkan sesuai dengan wujudnya, yaitu binatang, sedangkan dalam wujud antropomorfik berarti wahana tersebut digambarkan dalam wujud setengah manusia setengah hewan (badan manusia kepala hewan). Wahana dalam bentuk antropomorfik sangat jarang ditemukan. Pada koleksi di Museum Nasional ditemukan wahana yang digambarkan dengan tubuh manusia, yaitu nandi, garuda, dan hamsa. Ketiganya merupakan wahana dari dewa Trimurti (Siwa, Wisnu dan Brahma) dan digambarkan sedang menopang para dewa tersebut di atas bahunya. Keterangan tersebut memberikan informasi bahwa meski wahana digambarkan dalam wujud antropomorfik, penggambarannya selalu diikuti oleh para dewanya.

Berdasarkan pada kajian ikonografis dan keterangan di atas maka dapat disimpulkan bahwa arca tokoh koleksi Museum Penataran yang memiliki wajah singa tersebut bukanlah suatu wahana tetapi merujuk pada dewa. Berdasarkan pada ciri ikonografik khususnya diketahui bahwa tokoh tersebut adalah Dewa Ganesha dan melalui identifikasi berbagai perwujudan Ganesha yang ada di berbagai teks kuno maupun pahatan diketahui bahwa nama tokoh tersebut adalah Simha-Ganapati.

(Bühnemann, 1955, hlm. 8-10) dalam bukunya menyebutkan bahwa tokoh Simha-Ganapati ini memiliki beberapa ciri. Ciri yang mencolok adalah wajah yang merupakan kombinasi dari dua binatang yaitu berwajah singa yang memiliki belalai gajah. Ciri lainnya ditunjukkan melalui tangan yang berjumlah delapan dan masing-masing memiliki gestur serta memegang benda tertentu, antara lain sisi kanan membawa kecapi, pohon pengharapan, cakra, dan bersikap varadamudra, sedangkan bagian kiri membawa padma merah, wadah/ guci/ bejana, sekelompok bunga, dan bersikap abhayamudra. Gambaran yang sama dijumpai pada Simha-Ganapati yang membawa kecapi di tangan kanan bawah selain adanya kalpalata, varamudra, padma, ratnakumbha, dan puspamanjari di lima tangan lainnya (Chandrika, 2007, hlm. 48).

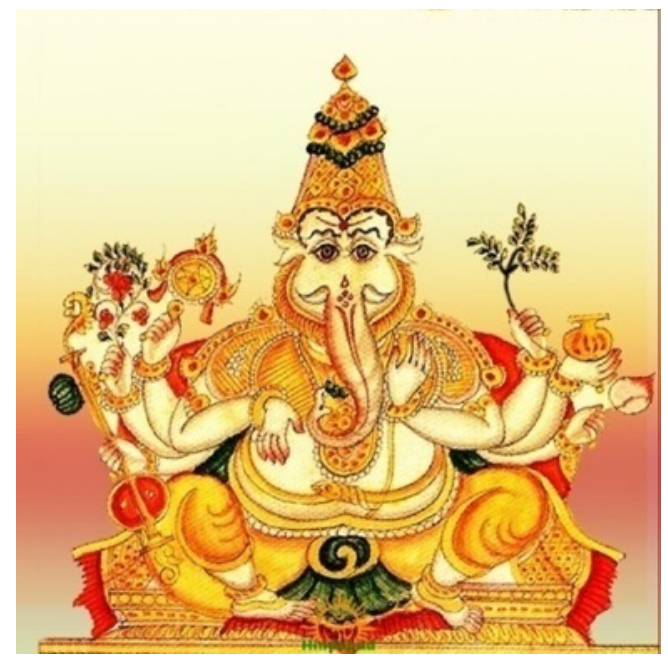

Gambar 13. Wujud Simha-Ganapati dalam bentuk dua dimensi

(Sumber: Sanagala, 2015) 
Penggambaran Simha-Ganapati yang diungkap oleh dari Bühnemann dan Chandrika sangat berbeda dengan penggambaran tokoh yang ada di Museum Penataran. Perbedaan ini bukanlah hal baru dalam seni kuno Nusantara. Beberapa temuan artefak yang terkait dengan seni kuno Nusantara memiliki perbedaan dengan seni kuno India. Hal ini disebabkan adanya penyesuaian perspektif dan karakteristik masyarakat lokal yang berkembang di Nusantara pada saat itu (Prawira, 2001, hlm. 3-6).

Secara umum, maksud dan tujuan pemujaan terhadap Simha-Ganapati tidak terlalu berbeda dengan pemujaan terhadap Ganesha. Apabila pemujaan terhadap Ganesha memiliki maksud dan tujuan untuk menghindarkan manusia dari segala macam mara bahaya dan ketakutan maka pemujaan terhadap SimhaGanapati menyimbolkan kekuatan dan keberanian (Sanagala, 2015). Hal senada juga diungkapkan oleh Rajendran (2017) yang menyebutkan bahwa pemujaan terhadap Simha-Ganapati akan memberikan kepercayaan diri dan keberanian dalam menghadapi permasalahan kehidupan dengan cara menghancurkan semua bentuk pikiran dan unsur-unsur negatif.

\section{KESIMPULAN}

Berdasarkan pada hasil analisis ikonografi ciri khusus dan melakukan perbandingan dengan berbagai arca yang memiliki kedekatan morfologi diperoleh hasil bahwa arca tokoh berkepala singa di Museum Penataran merupakan Dewa Ganesha dalam wujud Simha-Ganapati. Simha-Ganapati merupakan salah satu wujud Ganesha yang diperkirakan dipuja sebagai salah satu media untuk menghilangkan segala pikiran negatif yang muncul sehingga para pemujanya dapat menghadapi setiap permasalahan kehidupannya dengan tenang. Secara ikonografis, Simha-Ganapati digambarkan memiliki wajah gabungan antara singa dan gajah serta memiliki enam sampai delapan tangan yang masing-masing tangan membentuk gestur dan membawa benda tertentu. Ciri ikonografis tersebut sangat berbeda jika dibandingkan dengan arca di Museum Penataran. Namun, hal tersebut dapat dianggap sebagai salah satu bentuk penyesuaian seniman masa lalu terhadap perspektif dan karakteristik yang dimiliki oleh masyarakat Nusantara masa lalu. 


\section{DAFTAR PUSTAKA}

Agoramoorthy, Govindasamy; Hsu, M. J. (2012). The Significance of Cows in India Society between Sacredness and Economy. Antropological Notebooks, 18(3), 5-12.

Ball, K. M. (2004). Animal Motifs in Asian Art: An Illustrated Guide to Their Meanings and Aesthetics. New York: Dover Publications, Inc.

BPCB Jateng, 2017. Mengulik Belalai Arca Ganesha. Diunduh dari https:/ / kebudayaan.kemdikbud.go.id/bpcbjateng/mengulik-belalai-arcaganesha/.

Bühnemann, G. (1955). Tantric Forms of Ganeśa: According to the Vidyārņavatantra. New Delhi: D.K. Printworld (P) Ltd.

Chandrika, V. S. (2007). Analytical Study of the Musical Compositions in Praise of Lord Ganapati. University of Kerala.

Chinmayananda, S. (1986). Glory og Ganesha. Bombay: Central Chinmaya Mission Trust.

Choskyi, J. (1988). Symbolism of Animals in Buddhism. Buddhist Himalaya I (I). tanpa halaman. Diunduh dari http:/ / buddhim.20m.com/1-7.htm

Choskyi, V. J. (1988). Symbolism of Animals in Buddhism. BUddhist Himalaya, $\mathrm{I}(\mathrm{I})$.

Deka, D. (2010). Evolution of the Cult of Ganesa in Ancient and Medieval Assam. Universoty of Gaumati.

Geer, A. van der. (2008). Animals in Stone: Indian Mammals Sculptured Through Time. Leiden: Koninklijke Brill NV.

Gupte, R. S. (1972). Iconography of the Hindus, Buddhists, and Jains. Bombay: D.B. Taraporevala Sons \& Co. Private Ltd.

Hadiyanta, Eka; Romawati, Sri Muryantini; Tanzaq, Y. (2014). Katalog Koleksi Arca Batu. (E. Astuti, Wahyu; Hadiyanta, Ed.). Yogyakarta: Balai Pelestarian Cagar Budaya Yogyakarta.

Haryono, T. (1980). Singa Dalam Kesenian Hindu di Jawa Tengah. Berkala Arkeologi, 1(1), 42-51. https://doi.org/10.30883/jba.v1i1.275

Jouveau-Dubreuil, G. (1937). Iconography of Southern India. Paris: Librairie Orientaliste Paul Geuthner.

Khosravifard, Sam; Niamir, A. (2016). The Lair of the Lion in Iran. Cats in Iran Special Issue. Bern.

Kouli, D. R. (2012). Art and Iconography of the Sculpture of Kamrup District of Assam (From the 5th Century A.D. to the 18th Century A.D.). Gauhati University.

Kumaran, T. S. (tanpa tahun). Ganesha. E-book. Diunduh dari http://cincinnatitemple.com/wp-content/uploads/images/pdf/Ganeshae-Book.pdf 
Museum Nasional. 2018. (tanpa judul) Diunduh dari https://twitter.com/museumnasional/status/961138767498219520.

Nayar, P. (2016). Narasimha Sculptures of Kerala: An Analysis of Their Diversity. In N. Krishna (Ed.), Iconography of The Hindus, Buddhists \& Jains (pp. 166178). Chennai: C.P.R. Publications.

Nilotama, S. K. L. (2009). Makna Simbol Gelar Raja dalam Masyarkaat Adat Bali. Jurnal Visual Art \& Design, 3(1), 43-56.

Nozedar, A. (2008). Element Encyclopedia of Secret Signs and Symbols: The Ultimate A-Z Guide from Alchemy to the Zodiac. London: Harper Element.

Ohnuma, R. (2016). Animal Doubles of the Buddha. Humanimalia: A Journal of Human/Animal Interface Studies, 7(2), 1-34.

Perpustakaan Nasional. (tanpa tahun). Candi Prambanan. Diunduh dari http://candi.perpusnas.go.id/temples/deskripsi-yogyakartacandi_prambanan 8 .

Prawira, N. G. (2001). Seni Rupa Indonesia-Hindu: Penemuan Jatidiri dan Puncak Perkembangan Seni Rupa Indonesia-Lama pada Zaman Singhasari dan Majapahit di Jawa Timur. Jurnal Seni Rupa Dan Desain, volume 1(3), 1-14.

Rajendran, Abhilash. 2017. Simha Ganapati Form of Ganesha. Diunduh dari https://www.hindu-blog.com/2011/09/simha-ganapati-form-ofganesha.html?m=1.

Rao, G. (1914). Elements of Hindu Iconography Vol. I-Part I. Madras: The Law Printing House.

Ray, N. (1977). Animal Symbols in Maurya Art: Formal and Cultural Significance.

Reddy, N. V. (1995). Ganesa in Art and Epigraphy in Andhra Pradesh. Sri Venkateswara University.

Redig, I. W. (1992). A Comparative Study of Ganesa Images from India and Indonesia (From Circa 7th to 15th Century A.D.). Panjab University.

Restiyadi, A. (2012). Penggambaran Singa di Padang Lawas, Provinsi Sumatera Utara (Seni Warisan Budaya Sumatera Bagian Utara: Fauna dalam Arkeologi No. 0312). Medan.

Sanagala, Naveen. 2015. Simha Ganapati, the Lion Faced Ganesha. Diunduh dari https://hindupad.com/simha-ganapati-the -lion-faced-ganesha/.

Sedyawati, E. (1994). Pengarcaan Gaņeśa Masa Kadiri dan Sinhasāri: Sebuah Tinjauan Sejarah Kesenian. Jakarta: LIPI-Rul.

Soedibyo, E. S. (1984). Arca Siva Trisirah di Jawa: Sebuah Kajian Hipotesis. Universitas Indonesia.

Suresh, K. M. (1991). Sculptural Art of Hampi. Utkal University Bhubaneshwar.

Tanpa penulis. Tanpa tahun. Museum Penataran Blitar. Diunduh dari https://situsbudaya.id/museum-penataran-blitar/ 
Lampiran 1. Kelompok Ganesha (disebut dengan nama Ganapati) dalam 16 Wujud
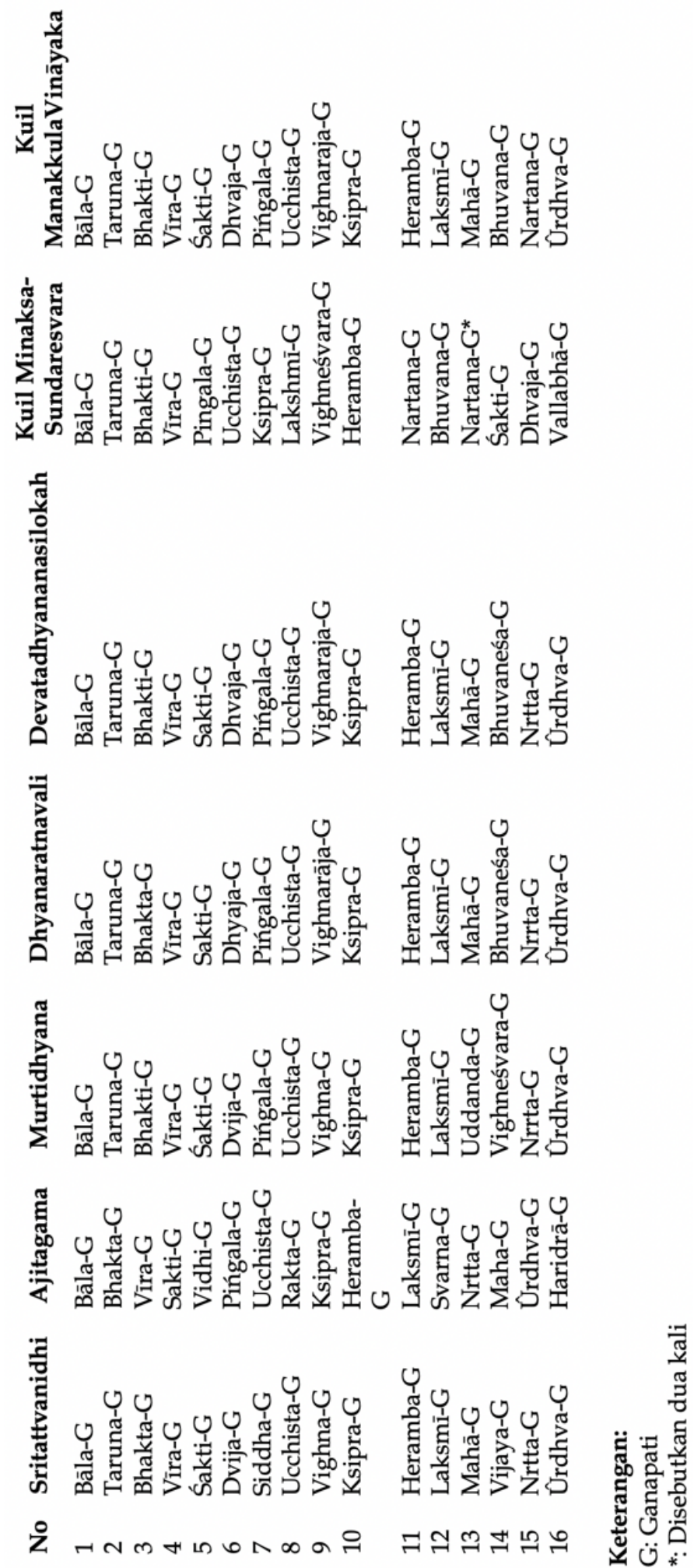

(Sumber: Bühnemann, 1955: 2) 
Lampiran 2. Kelompok Ganesha (disebut dengan nama Ganapati) dalam 32 Wujud

(Sumber: Bühnemann, 1955: 5-10)

\begin{tabular}{ll} 
No & \multicolumn{1}{c}{ Nama } \\
1 & Bāla Ganapati \\
2 & Taruna Ganapati \\
3 & Bhakta Ganapati \\
4 & Vìra Ganapati \\
5 & Śakti Ganapati \\
6 & Dvija Ganapati \\
7 & Siddha Ganapati \\
& \\
8 & Ucchista Ganapati \\
9 & Vighna Ganapati \\
10 & Ksipra Ganapati \\
11 & Heramba Ganapati \\
12 & Laksmī Ganapati \\
13 & Mahā Ganapati \\
14 & Vijaya Ganapati \\
15 & Nrtta Ganapati / Kalpanrtta \\
& Ganapati \\
16 & Urrdhva Ganapati
\end{tabular}

\begin{tabular}{ll} 
No & \multicolumn{1}{c}{ Keterangan } \\
17 & Ekāksara Ganapati \\
18 & Vara Ganapati \\
19 & Tryaksara Ganapati \\
20 & Ksipraprasāda Ganapati \\
21 & Haridrā Ganapati \\
22 & Ekadanta Ganapati \\
23 & Srsti Ganapati / Srstidaksa \\
& Ganapati \\
24 & Uddanda Ganapati \\
25 & Rnamocaka / mocanaka Ganapati \\
26 & Dhundi Ganapati \\
27 & Dvimukha Ganapati \\
28 & Trimukha Ganapati \\
29 & Simha Ganapati \\
30 & Yoga Ganapati \\
31 & Durga Ganapati \\
& \\
32 & Samkastahara / Samkataharaka \\
& Ganapati
\end{tabular}

Lampiran 3. Kelompok Ganeshadalam 51 Wujud (Sumber: Bühnemann, 1955: 12)

$\begin{array}{llllll}\text { No } & \text { Nama } & \text { Pasangan } & \text { No } & \text { Nama } & \text { Pasangan } \\ 1 & \text { Vighneśa } & \text { Śri } & 27 & \text { Sumukha } & \text { Bhūti } \\ 2 & \text { Vighnarāja } & \text { Hrī } & 28 & \text { Pramodaka } & \text { Bhûmi } \\ 3 & \text { Vināyaka } & \text { Tusti } & 29 & \text { Ekapāda } & \text { Satī } \\ 4 & \text { Śivottama } & \text { Sānti } & 30 & \text { Dvijihva } & \text { Ramyā } \\ 5 & \text { Vighnakrt } & \text { Pusti } & 31 & \text { Śūra } & \text { Mānusī } \\ 6 & \text { Vighnahartr } & \text { Sarasvatī } & 32 & \text { Vīra } & \text { Makaradhvajā } \\ 7 & \text { Ganarāj } & \text { Ramā } & 33 & \text { Sanmukha } & \text { Vikarnā } \\ 8 & \text { Gananāyaka } & \text { Medhā } & 34 & \text { Varada } & \text { Bhrukutī } \\ 9 & \text { Ekadanta } & \text { Kānti } & 35 & \text { Vāmadeva } & \text { Lajjā } \\ 10 & \text { Dvidanta } & \text { Kāminī } & 36 & \text { Vakratunda } & \text { Dīrghaghonā } \\ 11 & \text { Gajavaktra } & \text { Mohini } & 37 & \text { Dvirandaka } & \text { Dhanurdharā } \\ 12 & \text { Nirañjana } & \text { Balā } & 38 & \text { Senāni } & \text { Yāmin̄ī } \\ 13 & \text { Kapardavān } & \text { Tīvrā } & 39 & \text { Grāmani } & \text { Rātri } \\ 14 & \text { Dīrghamukha } & \text { Jvàlini } & 40 & \text { Matta } & \text { Candrakāntā } \\ 15 & \text { Sankukarna } & \text { Nanda } & 41 & \text { Vimatta } & \text { Saśiprabhā } \\ 16 & \text { Vrsadhvaja } & \text { Surasā } & 42 & \text { Mattavāhana } & \text { Lolāksi } \\ 17 & \text { Gananātha } & \text { Kāmarûpini } & 43 & \text { Jatin } & \text { Capalā } \\ 18 & \text { Gajendra } & \text { Ugrā } & 44 & \text { Mundin } & \text { Rddhi }\end{array}$




$\begin{array}{lllrll}19 & \text { Surpakarna } & \text { Jayin̄̄ } & 45 & \text { Khadgin } & \text { Durbhagā } \\ 20 & \text { Trilocana } & \text { Satyā } & 46 & \text { Varenya } & \text { Subhagā } \\ 21 & \text { Lambodara } & \text { Vighneśanī } & 47 & \text { Vrsaketana } & \text { Śivā } \\ 22 & \text { Mahānāda } & \text { Surûpinī } & 48 & \text { Bhaksyapriya } & \text { Durgā } \\ 23 & \text { Caturmûrti } & \text { Kāmadā } & 49 & \text { Ganeśa } & \text { Guhapriya } \\ 24 & \text { Sadāśiva } & \text { Madajihnvā } & 50 & \text { Meghanāda } & \text { Kālī } \\ 25 & \text { Āmoda } & \text { Vikatā } & 51 & \text { Ganeśvara } & \text { Lalajjihvā } \\ 26 & \text { Durmukha } & \text { Ghûrnitānanā } & & & \end{array}$

Lampiran 4. Kelompok Ganesha (disebut dengan nama Vināyaka) dalam 56 Wujud

(Sumber: Bühnemann, 1955: 13-15)

\section{Lapisan 1}

1. Arka Vināyaka

5. Uddanda Vināyaka

2. Durga Vināyaka

6. Pāśapāni Vināyaka

3. Bhīmacanda Vināyaka

7. Kharva Vināyaka

4. Dehali Vināyaka

8. Siddhi Vināyaka

\section{Lapisan 2}

9. Lambodara Vināyaka

13. Munda Vināyaka

10. Kūtandanta Vināyaka

14. Vikatadvija Vināyaka

11. Śālakatankata Vināyaka

15. Rājaputra Vināyaka

12. Kūsmānda Vināyaka

16. Pranava Vināyaka

\section{Lapisan 3}

17. Vakratunda Vināyaka

18. Ekadantaka Vināyaka

19. Trimukha Vināyaka

20. Pañcāsya Vināyaka

21. Heramba Vināyaka

22. Vighnarāja Vināyaka

23. Varada Vināyaka

24. Modakapriya Vināyaka

\section{Lapisan 4}

25. Abhaya(pra)da Vināyaka

29. Cintāmani Vināyaka

26. Simhatunda Vināyaka

30. Dantahasta Vināyaka

27. Kunitāksa Vināyaka

31. Picindila Vināyaka

28. Ksipraprasādana Vināyaka

32. Uddandamunda Vināyaka

\section{Lapisan 5}

33. Sthūladanta Vināyaka

34. Kalipriya Vināyaka

35. Caturdanta Vināyaka

36. Dvitunda Vināyaka

37. Jyestha Vināyaka

38. Gaja Vināyaka

39. Kāla Vināyaka

40. Nāgeśa Vināyaka 


\section{Lapisan 6}

41. Manikarna Vināyaka

42. Āsa Vināyaka

43. Srsti Vināyaka

44. Yaksa Vināyaka

\section{Lapisan 7}

49. Moda Vināyaka

50. Pramoda Vināyaka

51. Sumukha Vināyaka

52. Durmukha Vināyaka
45. Gajakarna Vināyaka

46. Citraghanta Vināyaka

47. Sthūlajangha Vināyaka

48. Mangala Vināyaka / Mitra Vināyaka

53. Gananāyaka Vināyaka

54. Jñāna Vināyaka

55. Dvāra Vināyaka

56. Avimukta Vināyaka 